\title{
ION EXCHANGE CHROMATOGRAPHY WITH CONDUCTIVITY DETECTION COMPARED TO SPECTROPHOTOMETRY TO ASSAY PHOSPHATE IN MILK AND MILK PRODUCTS
}

\author{
[Tehnik Kromatografi Pertukaran Ion dengan Deteksi Konduktivitas dibandingkan dengan \\ Tehnik Spektrofotometri untuk Menentukan Fosfat dalam Susu dan Produknya]
}

\author{
Tia Amina Setiawati ${ }^{1)}$, Fanny Guyomarc' ${ }^{2) \star}$, Eric Beaucher ${ }^{2)}$, and Frederic Gaucheron ${ }^{2)}$ \\ 1) Faculty of Agriculture Industrial Technology, Universitas Padjadjaran, Bandung, Bandung, Indonesia \\ 2) Science et Technologie du Lait et de I'OEuf, UMR 1253 INRA-Agrocampus Ouest, Rennes, France
}

Approved April $09^{\text {th }} 2015 /$ Accepted June $23^{\text {rd }} 2015$

\begin{abstract}
Phosphorus is a critical dietary mineral that is involved as phosphate in bone, tooth, nucleic acids or phos pholipids and is mainly supplied through consumption of dairyproducts. Hence, it is important to be able to accurately and efficiently assay phosphate in dairy products. Currently, a colorimetric International Standard Organisation (ISO) reference method is us ed to assay phosphate in milk and cheese. This method requires large amounts of samples, of hamful chemicals and of manpower. In this paper, ionic exchange chromatography was used to assay phosphate on acid milk ultrafiltration permeate, milk, various cheeses and processed cheese and compared to the ISO method. The chromatographic method requires little amounts of materials and is automated. On the other hand, accuracy and precision were found to be less than those obtained with the reference method. In particular, phosphate was underestimated by the chromatographic method. Therefore, the chromatographic method is currently competitive for compar ative assays, but not for absolute quantitation of phosphate. Research is still needed to fully upgrade the performances of this environment-friendly and time-saving method to those of the ISO reference.
\end{abstract}

Keywords: cheese, ion-exchange chromatography, milk, phosphate

\begin{abstract}
ABSTRAK
Fosfor merupakan mineral penting dalam pembentukan fosfat dalam tulang, gigi, asam nukleat ataupun fosfolipid dan sebagian besar terpenuhi kebutuhannya dengan mengonsumsi produk-produk susu. Sehingga pengujian fosfat sangatlah penting untuk dilakukan secara akurat dan juga effisien dalam produk-produk susu tersebut. Saat ini, metode standar ISO untuk mengukur fosfat dalam susu dan keju adalah metode kolorimetri. Pada metode ini, dibutuhkan contoh dalam jumlah banyak, pereaksi yang menugikan kesehatan serta waktu dan tenaga yang banyak pula. Dalam tulisan ini metode kromatografi pertukaran ion digunakan sebagai metode pemb anding dalam pengujian fosfat pada susu, milk ultrafiltration permeate, beb erapa jenis keju dan keju olahan. Metode kromatografi ini membutuhkan contoh dan pereaksi yang relatif kecil dibandingkan dengan metode standar dan juga dilakukan secara otomatis. Akan tetapi akurasi dan presisinya masih relatif rendah dibanding metode standar. Metode kromatografi dalam pengujian fosfat masih belum banyak digunakan. Namun demikian metode kromatorafi ini dapat digunakan sebagai metode komparatif, namun tidak untuk dijadikan satu satunya pengujian fosfat secara kuantitatif. Penelitian lebih lanjut masih diperlukan untuk lebih meningkatkan performa dari metode ramah lingkungan dan hemat waktu ini sehingga bisa digunakan sebagai metode standar ISO.
\end{abstract}

Kata kunci: fosfat, keju, kromatografipertukaran ion, susu

${ }^{*}$ Corresponding Author :

Email: Fanny.Guyomarch@rennes.inra.fr 


\section{INTRODUCTION}

Phosphorus is an essential dietary mineral that is largely provided by dairy products in western diets (Dror and Allen, 2013; Lee and Cho, 2015). In milk and dairy products, phosphorus exists under different chemical forms (inorganic and organic forms) and in different localizations (free, associated to calcium in aqueous phase or associated to casein molecules in casein micelles, crystallized at the surface of some cheeses - Gaucheron, 2004; Walstra et al., 2006). The inorganic form of phosphorus is the orthophosphate which can exist differently ionized a as function of $\mathrm{pH}\left(\mathrm{H}_{2} \mathrm{PO}_{4}^{-}\right.$and $\left.\mathrm{HPO}_{4}{ }^{2-}\right)$. In the aqueous phase, these inorganic forms can coexist as free ion and associated to calcium to form calcium phosphate salt. Another part of this orthophosphate is associated to casein micelles and forms the colloidal calcium phosphate. It is admitted that this colloidal calcium phosphate plays roles in the structure and stability of casein micelles (Koutina and Skibsted, 2015). The organic form of phosphorus corresponds to those associated to different molecules. The main phosphorylated molecules are phosphoseryl residu- es present in casein micelles $(7.5 \mathrm{mM}$ in milk). It exits also minor phosphorylated molecules like phosphorylated sugars, phospholipids, nucleotides and nucleic acids. Finally, phosphate salts can be used in the manufacture of processed cheeses. In these products, the phosphate forms correspond mainly to pyrophosphate and polyphosphate. These salts ensure the smooth texture by modifying the casein's properties. Both for nutritional and technological issues, the precise assay of phosphorus in dairy products is therefore essential. Total phosphorus is currently assayed using the reference method ISO 9874/IDF 42 (IDF, 2006) for milk, and ISO 2962/IDF 33 (IDF, 2010) for cheese and processed cheese. It has also successfully been tested for casein phosphopeptides and infant formula milks (Miquel et al., 2004). The principle of these colorimetric methods is to mineralize the samples so that all phosphorus is converted to orthophosphate, which reacts with ammonium molybdate to finally yield molybdenum blue that is measured spectrophotometrically. However, this method requires large amounts of materials, involves toxic/corrosive materials and can be time consuming since all samples are processed individually.

In soil water extracts, Masson et al. (2001) demonstrated that soluble phosphate can be determined using ion exchange chromatography (IEC) with higher accuracy than by the above colorimetric method. Since the end of the 1990s, the IEC technique has attracted growing interest to assay anions and cations of foodstuff (Buldini et al., 1997; Ruiz-Calero and Galceran, 2005). The anions of milk and dairy products, including orthophosphate, can be successfully detected by ion exchange chromatography coupled with suppressed conductivity detection (Gaucheron et al., 1996; Buldini et al., 2002; Rulliere et al., 2013) but nothing is known of the comparative value of the IEC method to assay phosphorus in milk and in different dairy products, when compared to the ISO references. In the IEC method, only little amounts of samples (about 2 $\mathrm{mg} / \mathrm{kg}$ of phosphate) are required and no chemical is necessary other than $\mathrm{HCl}$ and $\mathrm{NaOH}$ during the preparation and analysis of the samples. Furthermore, samples are analyzed in series in programmed equipment, which spares time. Although investment can be costly, the method therefore shows potential interest with respect to environment and manpower.

The objective of the present study was therefore to evaluate the correctness and precision of an alternative method, namely IEC, to assay total phosphorus in different dairy products such as milk, aqueous phase of acidified milk and 3 types of cheeses, including one processed cheese containing polyphosphate salts. To assess correctness of the IEC method, the determined phosphate concentrations were compared to those obtained with the spectrophotometric method, regarded as the internationally approved reference method. The spectrophotometric method has indeed been previously evaluated as accurate, through the total recovery of phosphorus in certified reference materials, including dairy matrices (Cardoso Silveira et al., 2011; Miquel et al., 2004; Jastrzębska et al., 2003; de la Fuente and Juárez, 1995). Therefore, the IEC method is considered as correct if the phosphate concentrations are found the same as those determined with the reference ISO method, all other conditions being equal. To assess precision of the IEC method, dispersion of the results obtained with the IEC method is calculated as a tolerance interval. This interval is compared to that of the reference method. If the interval of the IEC method is respectively larger or smaller than that of the reference method, the IEC method is regarded as less or more precise than the reference.

\section{MATERIALS AND METHODS}

\section{Materials}

Skim milk was reconstituted by dispersing $10 \%$ $\mathrm{w} / \mathrm{w}$ of low heat skim powder (Lactalis, France) at room temperature in ultrapure MilliQ water $(18 \mathrm{~m} \Omega$, Millipore, Molsheim, France) and stirred for 50 min. Acid milk ultrafiltrate was obtained from skimmed milk equilibrated at $\sim 45^{\circ} \mathrm{C}$ then acidified to $\mathrm{pH} 4.6$ in 1 hour at $4^{\circ} \mathrm{C}$ using lactic acid and gentle stirring. The acidified milk was kept at $4^{\circ} \mathrm{C}$ overnight to ensure equilibration while preventing precipitation. The milk 
was then heated at $25^{\circ} \mathrm{C}$ and $\mathrm{pH}$ was further adjusted to 4.6 to induce precipitation of the casein molecules. The clear phase was then ultrafiltered at $25^{\circ} \mathrm{C}$ using in $8 \mathrm{kDa}$ molecular weight cut-off pilot-plant mineral membrane with a surface of $6.65 \mathrm{~m}^{2}$ (Tami Industries, Nyons, France), to remove whey proteins, then cooled to $4^{\circ} \mathrm{C}$. The resulting fraction was called acid milk ultrafiltrate (AMU). Retail cheeses (Raclette, Babybel and Vache Qui Rit) were bought on a local supermarket. Raclette cheese and Babybel are both semi-hard chees es; Raclette was ripened 3-6 months while Babybel was only lightly ripened. Ripening should not influence the phosphorus content, but as it affects texture it may affect the performance of the methods. Finally, Vache Qui Rit is a processed cheese whose technology involves polyphosphates as melting salts to reach a smooth texture. Hence, the amount of total phosphorus is expected to be higher than in the 2 other cheeses. All chemical reagents were analytical grade. All glassware was specifically cleaned with phosphate-free detergents and doub-lerinsed with ultrapure water prior to use.

\section{pH determination}

The $\mathrm{pH}$ values were determined using a $\mathrm{pH}$ meter (HI 9024 microcomputer pH meter, Hanna Instruments, Romania) equipped with a $\mathrm{pH}$ electrode from Mettler Toledo (Toledo, Switzerland).

\section{Dry matter determination}

Total solids or dry matter (DM), was assayed on the samples using oven drying method as described in the standard method IDF 21B: 1987 (now updated as ISO 5534:2004, IISO, 2004). B riefly, samples were homogenized and $2 \mathrm{~g}$ of cheese, $5 \mathrm{~g}$ of reconstituted milk or $7 \mathrm{~g}$ for $\mathrm{AMU}$ were precisely weighted, dried in the oven at $120^{\circ} \mathrm{C}$ for $5 \mathrm{~h}$, cooled in a desiccator and weighted again in order to calculate the proportion of lost humidity and deduce DM.

\section{Total nitrogen measurement}

The total nitrogen content was determined by the Kjeldhal method according to FIL-IDF standard 20B:1993 (now updated as ISO 8968-1:2014, ISO, 2014). Briefly, samples were digested in $\mathrm{H}_{2} \mathrm{SO}_{4}$ (Prolabo, VWR, Strasbourg, France) in presence of copper and potassium sulfates as catalyzers (Foss France, Nanterre, France), to release ammonium salts $\mathrm{NH}_{4}{ }^{+}$, which is later converted in gas eous $\mathrm{NH}_{3}$ by $\mathrm{NaOH}$ (Carlo Erba, Val-de-Reuil, France). The ammoniac gas can be isolated by distillation into boric acid, and titrated using $\mathrm{HCl}$ (Carlo Erba). Nitrogen contents were converted into protein equivalent using 6.38 as multiplying conversion factor.

\section{Ashes measurement}

The ashes content was determined by mineralization at high temperature according to the references methods AFNOR NF-V-04-208 for milk and liquids and IDF 27:1964 for cheeses (now updated as ISO 5545:2008 AFNOR, 1989; ISO, 2008). Briefly, $5 \mathrm{~g}$ of milk, $10 \mathrm{~g}$ of AMU or $2 \mathrm{~g}$ of cheese were precisely weighted into a platinum or silica dish. The samples were then heated to dryness in an oven at $100^{\circ} \mathrm{C}$, heated in an electric furnace at $500^{\circ} \mathrm{C}$ for $5 \mathrm{~h}$, cooled in a desiccator and finally precisely weighted again to calculate the amount of ashes to the total initial mass of product.

\section{Assay of total phosphorus by the spectrophoto- metric method (ISO)}

Total phosphorus was determined according to the international standard methods ISO 9874/IDF 42 for milk and ISO 2962/IDF 33 for cheese and processed cheese products (IDF, 2006; IDF, 2010). Briefly, samples were homogenized and $5 \mathrm{~g}$ of reference or milk solutions, $10 \mathrm{~g}$ of $\mathrm{AMU}$ or $2 \mathrm{~g}$ of cheese were precisely weighted into a silica dish. The samples were mineralized at $550^{\circ} \mathrm{C}$ for $5 \mathrm{~h}$, so that all phosphorylated matter was converted in orthophosphate ions. The resulting ashes were dissolved in 3 $\mathrm{mL} \mathrm{HCl} 1 \mathrm{M}$ (Carlo Erba) for $\sim 15 \mathrm{~min}$ and adjusted to $100 \mathrm{~mL}$ with ultrapure water (Millipore). Then, orthophosphate ions reacted with ammonium molybdate (Prolabo) in acidic conditions to yield phosphormolybdic acid. This latter compound is further reduced by ascorbic acid (Prolabo) to yield molybdenum blue. Intensity of the color is proportional to the phosphorus concentration; hence, the absorbance was measured spectrophotometrically at a wavelength of $820 \mathrm{~nm}$ (near infrared Uvikon 922, BioTek Instruments, Colmar, France) and reported to the total phosphorus concentration using a calibration curve. The calibration curve was obtained after dilution of a mother solution of $\sim 450 \mathrm{mg} / \mathrm{L}$ of $\mathrm{KH}_{2} \mathrm{PO}_{4}$ (Carlo Erba) to have 5 solutions (from 0 to $1 \mathrm{mg} / \mathrm{kg}$ of phosphorus which correspond- ed from 0 to $3 \mathrm{mg} / \mathrm{kg}$ of phosphate). The correlation coefficient $R^{2}$ of the calibration curve was $99 \%$ and standard deviation was $<0.01 \mathrm{mg} / \mathrm{kg}$. Each result was an average of 3 repetitions, where 3 dilutions where used per repetition. Phosphorus concentrations were converted in phosphate concentrations by a multiplying factor of 3 . Results were expressed in $\mathrm{mg} / \mathrm{kg}$ of phosphate.

\section{Assay of phosphate by ionic exchange chromate- graphy (IEC)}

Alternatively, total phosphorus as orthophosphate ions were measured by ionic exchange chromatography using a Dionex Scientific ICS 3000 instrument (Dionex, Voisin-le-Bretonneux, France) as 
described by Gaucheron et al. (1996). Briefly, anions were separated with an lonPac AS11 hydroxideselective anion-exchange column, fitted with an AG11 guard column and an ASRS 300 suppressor that helps increase sensitivity through trapping contaminating ions from the mobile phase. The loaded sample anions ( $25 \mu \mathrm{L}$ injection volume) interacted with the stationary phase of the ion-exchange column at $30^{\circ} \mathrm{C}$ then were selectively desorbed by a stepwise increase in sodium concentration of the mobile phase from 0.5 to $34 \mathrm{mM} \mathrm{NaOH}$ (Carlo Erba) as described in Table 1. Flow-rate of the mobile phase was $1 \mathrm{~mL} / \mathrm{min}$.

Table 1. Elution gradient used for phosphate analysis by ionic exchange chromatography. Eluents $\mathrm{A}, \mathrm{B}$ and $\mathrm{C}$ were respectively $\mathrm{NaOH} 2 \mathrm{mM}, \mathrm{NaOH} 200 \mathrm{mM}$ and ultrapure MilliQ water (18 $\mathrm{m} \Omega$, Millipore)

\begin{tabular}{cccc}
\hline Time $(\mathrm{Min})$ & $\mathrm{A}(\%$ Vol $)$ & $\mathrm{B}(\%$ Vol $)$ & $\mathrm{C}(\%$ Vol $)$ \\
\hline 0 & 25.0 & 0 & 75.0 \\
4 & 25.0 & 0 & 75.0 \\
6 & 0 & 1.5 & 98.5 \\
18 & 0 & 15.0 & 85.0 \\
21 & 0 & 17.0 & 83.0 \\
22 & 0 & 17.0 & 83.0 \\
22.5 & 25.0 & 0 & 75.0 \\
34 & 25.0 & 0 & 75.0 \\
\hline
\end{tabular}

Chromatographic peaks were detected by conductimetry. Thus, the different anions contained in the samples desorb at specific retention times, yielding chromatographic peaks whose areas were proportional to the concentration of phosphate injected. A calibration curve was obtained using mineralized $\mathrm{KH}_{2} \mathrm{PO}_{4}$ solutions (Carlo Erba-five levels from 0 to $40 \mathrm{mg} / \mathrm{kg}$ of phosphate) and had a $R^{2}$ of $99.7 \%$ (standard deviation $<0.2 \mathrm{mg} / \mathrm{kg}$ ). Gaucheron et al., (1996) already showed that the IEC method for phosphate is linear in the $0-40 \mathrm{mg} / \mathrm{kg}$ concentration range. They also reported a detection limit of $\sim 10$ $\mu \mathrm{g} / \mathrm{kg}$ phosphate. Each result was an average of 3 repetitions, where 3 dilutions where used per repetition. Phosphate concentrations were expressed in $\mathrm{mg} / \mathrm{kg}$. When the redissolution of mineralized ashes was questioned, two alternative preparations were tested i.e. 1) dissolution of ashes in $1 \mathrm{M} \mathrm{HCl}$ (Carlo Erba) conducted overnight instead of 15 min and 2) dissolution of ashes in the presence of $3 \mathrm{M}$ $\mathrm{H}_{2} \mathrm{SO}_{4}$ (Prolabo) instead of $1 \mathrm{M} \mathrm{HCl}$ to ensure complete mineral solubilization. The related results were pooled and named IEC+.

\section{Precipitation test}

This test was performed to check whether alkalinization, which occurs in the chromatographic column with the IEC method, induced or not a precipitation of calcium phosphate in the sample upon injection, and hence, losses of phosphorus. The test was performed on milk, AMU and the raclette cheese. Samples were mineralized and diluted in $\mathrm{HCl}$ $1 \mathrm{M}$ (Carlo Erba) as described above. Then, they were adjusted to $\mathrm{pH} 12$ with $\mathrm{NaOH} 5 \mathrm{M}$ (Carlo Erba), stored for $50 \mathrm{~min}$ and centrifuged at $3000 \mathrm{~g}$ for 15 min. The centrifuged samples were visually observed to check possible insoluble material.

\section{Method assessment}

To assess for the correctness and precision of the IEC method, different concentrations of each type of samples were required. Hence, the low heat skim milk powder was dedicatedly reconstituted at 5, 10 and $20 \%(\mathrm{w} / \mathrm{w})$ as described above. AMU was used pure and diluted $1: 2$ and $1: 1 \mathrm{v} / \mathrm{v}$. The three cheeses were considered together as a set of solid dairy samples with different phosphorus concentrations. Assessment of the IEC method was performed using the INRA's application of the French standard NF V03-110 by Feinberg (2010) for the assessment of exactness of analytical methods. This application can be found in the form of an Open Office-compatible Excel sheet (Microsoft) that can be downloaded free of charge at http://www6.jouy.inra.fr/metarisk/Produc tions/Software-programs/Excel-templates/NF-V03-1 10 (last accessed April 2015). In brief, exactness can be defined as combined correctness and precision. From 3 repetitions $\times 3$ separate preparations $=9$ analyses, an average value of the concentration of phosphate is calculated for each 3 dilutions of each type of product. From this data, a tolerance interval is calculated according to Feinberg (2010) which defines the $80 \%$ dispersion range of the method. In other words, $80 \%$ of the phosphate analyses performed on the same type of sample and with the same method should yield a value within this range. In this work, the average and tolerance intervals are presented in solid black and dashed-dotted lines, respectively. They are compared with the reference ISO method, where the calculated average is shown as a black dashed line and where the confidence interval, in light grey, is set at $\pm 10 \%$ of the average for the AMU and milk products, and at $\pm 20 \%$ for the cheese. These values indeed encompass the observed dispersion of results for these method and products. The evaluated method is regarded as correct when the obtained average values meet those of the reference method, and it is regarded as precise when the obtained dispersion (tolerance interval) is equal or lower than that of the reference.

\section{RESULTS AND DISCUSSION}

\section{Physicochemical characterization of the samples \\ The DM content, the total protein content, ashes content (as an estimate of total minerals) and}


$\mathrm{pH}$ of the various milk products are shown on Figure 1. As expected, skim milk had a dry matter content of $94 \mathrm{~g} / \mathrm{kg}$, a total protein content of $33.3 \mathrm{~g} / \mathrm{kg}$ and an ashes content of $7.7 \mathrm{~g} / \mathrm{kg}$. These values were in the range of those usually reported for milk (Walstra et al., 2006). Compared to skim milk, the AMU had a lower dry matter of $54.6 \mathrm{~g} / \mathrm{kg}$, contained $6.4 \mathrm{~g} / \mathrm{kg}$ of ashes and virtually no proteins. The latter was 2.3 $\mathrm{g} / \mathrm{kg}$ in protein equivalent and corresponded to non-protein nitrogen molecules, such as peptides and urea (Walstra et al., 2006). Contents in ashes were higher in this AMU compared to those of aqueous phase of normal milk at $\mathrm{pH}$ 6.7. This was in accordance with the literature reporting that after milk acidification at $\mathrm{pH} 4.6$, the colloidal calcium phosphate is solubilized and present in the ultrafiltration permeate (Mekmene et al., 2010). Raclette and Babybel cheeses exhibited similar global composition, with 580 and $534 \mathrm{~g} / \mathrm{kg}$ DM respectively, 245 and $213 \mathrm{~g} / \mathrm{kg}$ total protein respectively and 30 and $36.6 \mathrm{~g} / \mathrm{kg}$ ashes, respectively. Again, these values were in agreement with those reported for semi-hard cheeses (Eck and Gillis, 2000). Finally, the Vache Qui Rit cheese had a lower $\mathrm{DM}$ at $404 \mathrm{~g} / \mathrm{kg}$ than the other cheeses, a lower total protein content $(115 \mathrm{~g} / \mathrm{kg})$ but a higher ashes content, determined at $40 \mathrm{~g} / \mathrm{kg}$. In proportion to the dry matter, the Vache Qui Rit cheese contained $28 \%$ of protein and up to $10 \%$ of ashes, while the 2 other cheeses contained $39-42 \%$ protein and $5-7 \%$ ashes. These differences of composition are explained by the notably different technologies of fabrication of semi-hard cheeses and melted cheeses. In Vache Qui Rit, butter and melting salts are added to the cheese mixture, and sugars are also present in the final product, which all contribute to decrease the part of proteins and increase that of minerals and especially phosphorus (Chambre et al., 2004).

\section{Assay of phosphorus: comparison of IEC to the reference spectrophotometric method}

The total phosphorus content of milk and 4 milk products was assayed using either the reference colorimetric method (ISO) or the ion-exchange chromatography (IEC). It is noteworthy that in the ISO method, the mineralized samples dissolved in $\mathrm{HCl}$ are further soaked in other acidic conditions (upon reaction with phosphomolybdic acid), which may help recover phosphate ions in solution. Meanwhile, the samples were directly analyzed by the IEC method. To check the possible effect of extended acidic contact, alternative sample preparations were tested for the IEC method, where the mineralized samples were soaked in $1 \mathrm{M} \mathrm{HCl}$ overnight instead of the standard 15 min or in $3 \mathrm{M} \mathrm{H}_{2} \mathrm{SO}_{4}$. The related results were pooled and are named IEC+. Figure 2 compares the average values found for each type of sample. Using the reference ISO method, the results showed that skim milk contained $955 \mathrm{mg} / \mathrm{kg}$ of phosphorus, which in agreement with expectations (Gaucheron et al., 1996; Mekmene et al., 2010; ANSES, 2013), while AMU contained $560 \mathrm{mg} / \mathrm{kg}$ (Figure 2). This difference is explained by the fact that $\mathrm{pH}$ induced solubilization of the colloidal calcium phosphate did not affect phosphate esters (organic phosphorus) e.g. phosphoserines, which are retained in the casein fraction, therefore not transferred to AMU. Raclette, Babybel and Vache Qui Rit cheeses had respective phosphate contents of 4.7, 3.9 and $5.1 \mathrm{~g} / \mathrm{kg}$ (Figure 2). When reported to the DM, Raclette, Babybel and Vache Qui Rit cheeses had respective phosphorus contents of $0.8,0.7$ and $1.2 \%$ w/w. Therefore, Vache Qui Rit showed the highest phosphorus concentration, due to the presence of polyphosphate salts in its manufacture (Chambre et al., 2004).

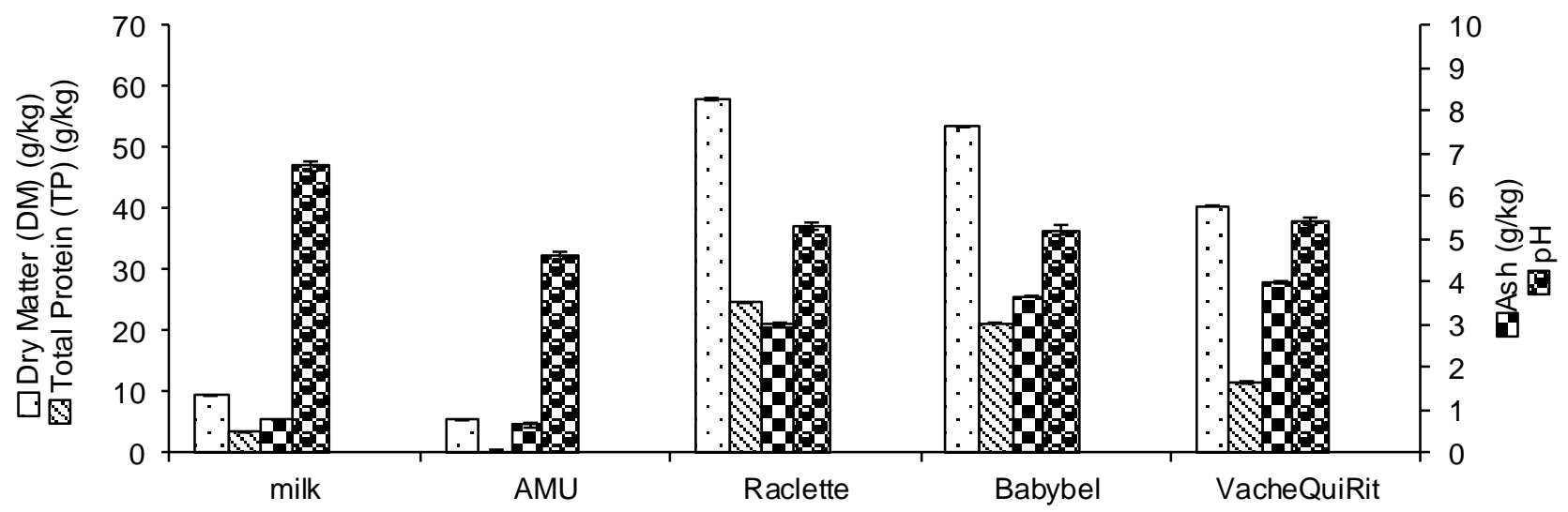

Figure 1. Dry matter content (DM), ashes content and total protein content (TP) of the skim milk, acidified milk ultrafiltrate (AMU) and 3 cheeses (Raclette, Babybel and Vache Qui Rit). Ashes and total protein contents are given relative to the DM. For DM and TP, each value is the average of 2 replicates $(\mathrm{N}=2)$. For ashes and $\mathrm{pH}, \mathrm{N}=3$ 
An important finding of this study is that values found using the IEC method were systematically lower than those found with the ISO method. On average and across all types of milk samples, the amount of phosphate found with the IEC method was $88 \pm 8 \%$ of the expected value found with the ISO reference method. Buldini et al. (1997), who used IEC with a different mineralization method to assay phosphorus in milk, did not back up their results with a reference method of quantitation and did not mention this issue. For milk and AMU, the decreases were about $-9 \%$ and $-15 \%$, respectively, while were about $-18,-14$ and $-24 \%$ for Raclette, Babybel and Vache Qui Rit cheeses, respectively. Figure 2 showed that an extended incubation of the IEC samples in acid to improve solubilization of phosphorus present in the mineralized ashes did not improve the results (IEC+ data in Figure 2). Therefore, the lower phosphorus contents found with the IEC method in comparison to ISO were not due to an incomplete resolubilization of all the phosphate contained in the mineralized samples. Hence, it seemed that the error was lower in AMU, and largest in Vache Qui Rit. Possibly, the correctness of the IEC method may depend on the initial structure of the phosphorus in the samples. If anions other than the simple orthophosphate forms were present after mineralization, e.g. polyphosphate forms, it may be that these forms could react with ammonium molybdate and hence be fully assayed by the ISO method, but not with IEC where such species would probably exhibit a different retention time than that of phosphate. Douglas and Field (1975) showed that pyrophosphate, for instance, could be converted into orthophosphate in the presence of molybdate in acidic and hot conditions, which are met in the first steps of the ISO assay. Rulliere et al. (2012) reported also hydrolysis of long-chain phosphates into orthophosphate and trimetaphosphate at $120^{\circ} \mathrm{C}$ for $10 \mathrm{~min}$ whereas heating the salts to $100^{\circ} \mathrm{C}$ in aqueous solutions had little effect on their composition. The presence of calcium increased the hydrolysis rate of long-chain phosphates and led to more trimetaphosphate and pyrophosphate as end products.

Another possible explication lays in the composition of the mobile phase used in the IEC method. Since this mobile phase contained alkaline $\mathrm{NaOH}$, it was suspected that some precipitation of calcium phosphate occurred upon sample injection. It is well known that calcium phosphate is insoluble at alkaline $\mathrm{pH}$ (Mekmene et al., 2012). To check this hypothesis, a calcium phosphate precipitation test was performed where mineralized samples of milk, AMU and Raclette cheese were alkalinized to $\mathrm{pH} 12$ using $\mathrm{NaOH}$. No visual precipitate was observed even after centrifugation of the samples (not shown), which suggested that such precipitation did not happen during IEC. However, a more sensitive method like size particle measurement by dynamic light scattering could be applied to support the results. Another approach that could be applied to check for phosphorus losses during IEC would be to analyze by the ISO method, the same sample prior to and after IEC analysis. However, this approach has limitations due to the different ranges of phosphate concentrations and masses involved in either method.

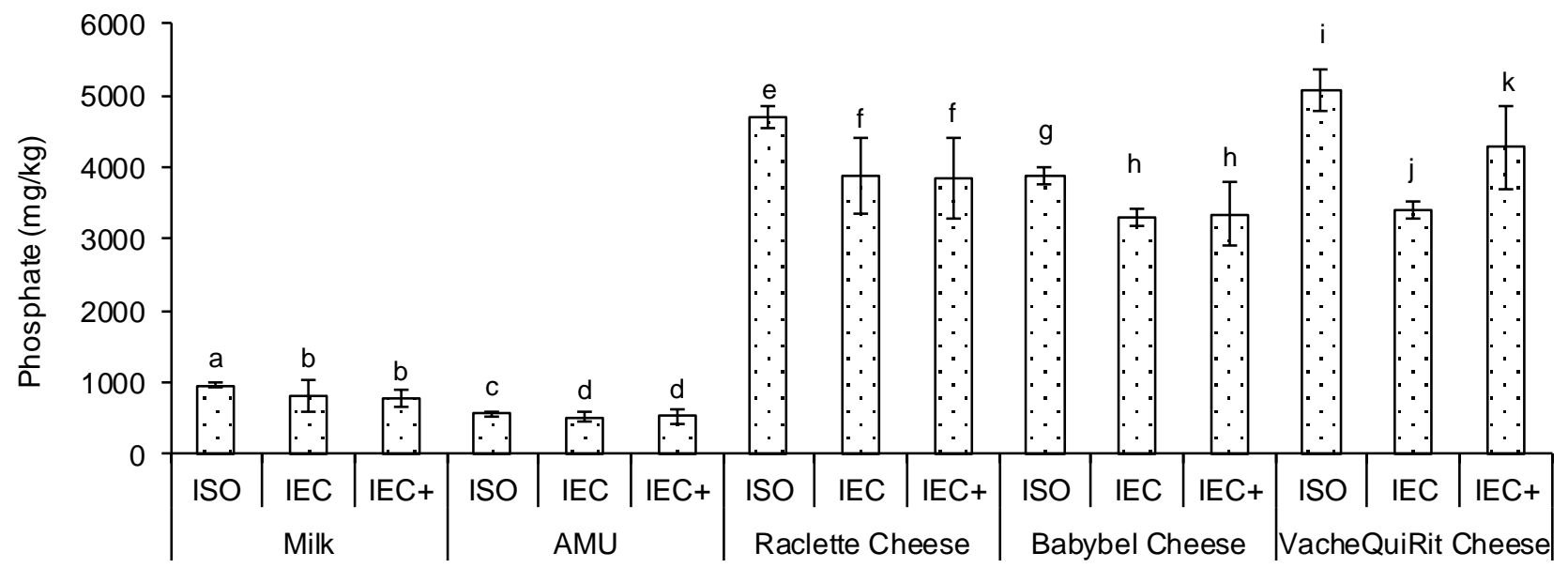

Figure 2. Total phosphate content found in skim milk (Milk), acid milk ultrafiltrate (AMU) and in the 3 cheeses (Raclette, Babybel and Vache qui rit) using the standard colori-metric method (ISO), the ion exchange chromatography (IEC) and IEC where the acidic soaking of samples was increased (IEC+). Differences were statistically tested only within data from the same type of product; different letters refer to statistically different results $(P<0.05)$. Each value is the average of 9 replicates $(\mathrm{N}=9)$ 


\section{Assessment}

In order to better compare the performances of the IEC method to the ISO reference, the average values of assayed phosphate found with each method and their respective dispersions were plotted together using the approach and tool described in Feinberg (2010). To assess for the correctness and precision of the IEC method over a wide range of phosphate contents, diluted AMU, AMU, diluted milk, milk, concentrated milk and the 3 cheeses Raclette, Babybel and Vache Qui Rit were used. The targeted performances of the IEC method are ideally those of the ISO method. Hence, the average phosphate contents that were actually measured with the ISO method for each concentration level of each type of product were taken as the $100 \%$ target (black dashed line ---- in Figure 3). The target confidence interval of the ISO method (light grey area between the dotted lines $\cdots . .$. in Figure 3 ) was taken as $\pm 10 \%$ of the $100 \%$ average values for milk and $\mathrm{AMU}$, and as $\pm 20 \%$ for cheeses (whereas the actual variation coefficients were actually below those values). Then, the individual data collected upon IEC analysis of all the samples were input in the INRA Excel NF-V03-110 assessment spreadsheet in order to calculate the average phosphate concentrations (open black circles and black line in Figure 3 ) and the tolerance interval (area between the lower and higher black dashed-dotted limits - -- -) found with the IEC method for each type of products (milk, AMU or cheese), over the range of phosphate concentrations assayed. The correctness of the tested method IEC is evaluated as the gap between the calculated concentrations and the $100 \%$ target. The precision of the tested method IEC is evaluated through comparing the range between limits with the reference confidence interval: a valid method should show dispersion lower or equal to that of the reference. As it is difficult to dilute solid matter, the required 3 different levels of phosphate contents for cheese were obtained by mixing the data obtained with the 3 different cheeses, Raclette, Babybel and Vache Qui Rit. Figure 3 summarizes the results found for the AMU, milk and cheeses. In agreement with the Figure 2, Figure 3 shows that the IEC method frequently underestimated the content of phosphate in the samples, which means that the IEC method was not fully correct. For all types of products, the difference was greater for the larger concentration of phosphate tested, even though correctness could be satisfactory for similar contents in another product (e.g. compare AMU and milk at 400-500 $\mathrm{mg} / \mathrm{kg}$ phosphorus). In general, confidence intervals were greater with the IEC method than with the reference ISO method, which means that it was found to be less precise.
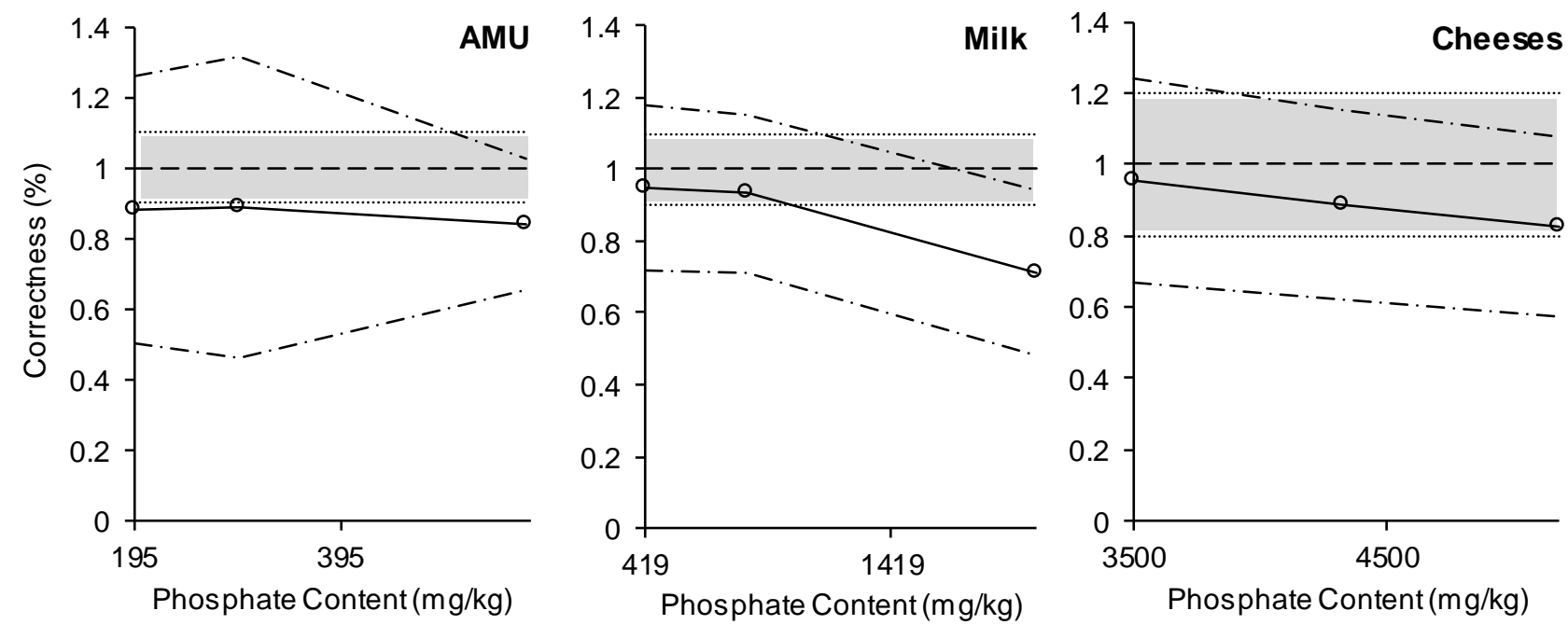

Figure 3. Average values and dispersion of the total phosphate contents found by the IEC method, in comparis on to that of the ISO method. In each graph, the black solid line and circles shows the values found by the IEC method, while the black dashed-dotted solid lines $\left.(-\because-)^{-}\right)$show the calculated lower and higher limits of the tolerance interval $(80 \%)$. The light grey area is the reference ISO target, where the central black dashed line (----) is the exact (targeted) phosphate content $(100 \%)$ and the black dotted lines (…) are the lower and higher limits of the confidence interval $( \pm 10 \%$ of the target in the case of $\mathrm{AMU}$ and milk, and $\pm 20 \%$ in the case of cheeses) 
This may be due to the smaller amounts of sample used during the IEC method, hence the possibly lower representativity of heterogeneous samples as dairy products. This could also be due to possible phosphate losses during IEC, as mentioned earlier, resulting in heterogeneity. If such losses exist, both accuracy and precision could be improved simultaneously through preventing them during IEC.

\section{CONCLUSION}

This study aimed at evaluating the performances of the IEC method to assay total phosphorus in milk products, in comparison to the colorimetric reference method ISO. In conclusion, the IEC was found less exact and less precise that the ISO method, possibly because of a difference in the sample's preparation and/or homogeneity. However, IEC has numerous advantages, as it allows analysis of series of samples and the parallel assay of various ions like chloride, citrate, sulfate (Buldini et al., 1997), with limited labour and environmental costs Therefore, perspectives for this work are either to apply correction coefficients, or to use the method only for relative comparison. Further research is needed to improve the performances of the IEC method up to quantitative standards.

\section{ACKNOWLEDGEMENTS}

Author Tia Amina Setiawati thanks the Islamic Development Bank, Jakarta, Indonesia, for financial support.

\section{REFERENCES}

[AFNOR] Agence Française de NORmalisation. 1989. Norme NF V04-208 Lait - Détermination des cendres - Méthode de référence. AFNOR, La Plaine Saint Denis, France.

[ANSES] Agence Nationale de SEcurité Sanitaire, de l'alimentation, de l'environnement et du travail. 2013. CIQUAL French food composition data by component: phosphorus. https://pro. anses.fr/TableCIQUAL/index.htm. [04 November 2014].

Buldini PL, Cavalli S, Sharma JL. 2002. Matrix removal for the ion chromatographic determination of some trace elements in milk. Microchem J 72: 277-284. DOI: 10.1016/S00 26-265X(02)00039-5.

Buldini PL, Cavalli S, Trifiró A. 1997. State-of-the-art ion chromatographic determination of inorganic ions in food. J Chromatogr A 789:
529-548. DOI: 10.1016/S0021-9673(97)0096 3-1.

Cardoso Silveira EL, de Caland LB, Tubino M. 2011. Molecular absorption spectrophotometric method for the determination of phosphorus in biodiesel. Fuel 90: 3485-3488. DOI: 10.1016/j. fuel.2011.06.020.

Chambre M, Goldschmidt B, Lecomte MC. 2004. Minéraux et fromage fondu. In: Minéraux et Produits Laitiers. 565-584. Tec et Doc Lavoisier, Paris, France.

De la Fuente M, Juárez M. 1995. Determination of phosphorus in dairy products by sample wet digestion in a microwave oven. Anal Chim Acta 309: 355-359. DOI: 10.1016/0003-2670(95) 00059-9.

Douglas LA, Field JFB. 1975. Determination of pyrophosphate and trace amounts of orthophosphate in solution. Anal Lett 8: 195-203. DOI: 10.1080/00032717508058198.

Dror DK, Allen LH. 2013. Dairy product intake in children and adolescents in developed countries: trends, nutritional contribution, and a review of association with health outcomes. Nutr Rev 72: 68-81. DOI: 10.1111/nure.12078.

Eck A, Gillis JC. 2000. Cheesemaking-from Science to Quality Assurance. Tec \& Doc Lavoisier, Paris, France.

Feinberg M. 2010. Principes et Vocabulaire Pour la Validation des Méthodes. In: Validation Des Méthodes D'Analyse Quantitative Par Profil D'Exactitude. 13-25. INRA, Paris, France.

Gaucheron F. 2004. Minéraux et Produits Laitiers. Tec \& Doc Lavoisier, Paris, France.

Gaucheron F, Le Graët Y, Piot M, Boyaval E. 1996. Determination of anions of milk by ion chromatography. Lait 76: 433-443.

[IDF] International Dairy Federation. 2010. ISO 2962/IDF 33. Cheese and Processed Cheese Products - Determination of Total Phosphorus Content - Molecular Absorption Spectrometric Method. IDF, Brussels, Belgium.

[IDF] International Dairy Federation. 2006. ISO 9874/IDF 42. Milk-Determination of Total Phosphorus Content-Method using Molecular Absorption Spectrometry. IDF, Brussels, Belgium.

[ISO] International Standard Organisation. 2014. ISO 8968-1:2014 (IDF 20-1:2014). Milk and milk products - Determination of Nitrogen ContentPart 1: Kjeldahl Principle and Crude Protein Calculation. ISO, Geneva, Switzerland. 
[ISO] International Standard Organisation. 2008. ISO 5545:2008 (IDF 90:2008). Rennet Casein and Caseinates-Determination of Ash (Reference Method). ISO, Geneva, Switzerland.

[ISO] International Standard Organisation. 2004. ISO 5534:2004 (IDF 4:2004). Cheese and Processed Cheese-Determination of the Total Solids Content (Reference method). ISO, Geneva, Switzerland.

Jastrzębska A, Brudka B, Szymański T, Szłyk E. 2003. Determination of phosphorus in food samples by X-ray fluorescence spectrometry and standard spectrophotometric method. Food Chem 83: 463-467. DOI 10.1016/ S0308-8146(03)00225-5.

Koutina G, Skibsted LH. 2015. Calcium and phosphorus equilibria during acidification of skim milk at elevated temperature. Int Dairy J 45: 1-7. DOI: 10.1016/j.idairyj.2015.01.006.

Lee AW, Cho SS. 2015. Association between phosphorus intake and bone health in the NHASES population. Nutr J 14: 28. DOI: 10.1186/s12937-015-0017-0.

Masson $\mathrm{P}$, Morel C, Martin E, Obers on A, Friesen D. 2001. Comparison of soluble $P$ in soil water extracts determined by ion chromatography, colorimetric, and inductively coupled plasma techniques in PPB range. Comm Soil Sci Plan 32: 2241-2253. DOI: 10.1081/CSS120000280.

Mekmene O, Leconte N, Rouillon T, Quillard S, Bouler JM, Gaucheron F. 2012. Physicochemical characterization of calcium phosphates prepared from milk ultrafiltrates: Effect of the mineral composition. Int J Dairy Technol 65: 1-8. DOI: 10.1111/j.1471-0307.2011. 00819.x.

Mekmene O, Le Graët Y, Gaucheron F. 2010. Theoretical model for calculating ionic equilibria in milk as a function of $\mathrm{pH}$ : comparison to experiment. J Agric Food Chem 58: 4440-4447. DOI: 10.1021/jf903628r.

Miquel E, Alegrìa A, Barberá R, Farré R. 2004. Microdetermination of phosphorus from infant formulas, casein and casein phosphopeptides. Eur Food Res Technol_219: 639-642. DOI: 10.1007/s00217-004-0994-2.

Ruiz-Calero V, Galceran MT. 2005. Ion chromatographic separations of phosphorus species: a review. Talanta 66: 376-410. DOI: 10.1016/j.talanta.2005.01.027.

Rulliere C, Rondeau-Mouro C, Raouche S, Defrechou M, Marchesseau S. 2013. Studies of polyphosphate composition and their interaction with dairy matrices by ion chromatography and P-31 NMR spectroscopy. Int Dairy J 28: 102-108. DOI: 10.1016/j. idairyj.2012.09.005.

Rulliere C, Perenes L, Senocq D, Dodi A, Marchesseau S. 2012. Heat treatment effect on polyphosphate chain length in aqueous and calcium solutions. Food Chem 134: 712-716. DOI: 10.1016/j.foodchem.2012.02.164.

Walstra P, Wouters JTM, Geurts TJ. 2006. Dairy Science and Technology. 2nd edition. CRC Press, Taylor and Francis Group, Boca Raton, Florida. 